\title{
Hematopoietic Cell Transplant Relapse Low Risk Rate
}

National Cancer Institute

\section{Source}

National Cancer Institute. Hematopoietic Cell Transplant Relapse Low Risk Rate. NCI

Thesaurus. Code C103153.

Risk of hematopoietic cell transplant relapse rates per patient year with $p$ value between 0.00 and 0.24 . 